\title{
Zrobotyzowane drukowanie 3D części maszyn metodami spawalniczymi
}

\author{
Robotized 3D printing of the machines parts \\ with welding methods
}

\section{Streszczenie}

Dotychczas praktykowana odbudowa zużytych części maszyn metodami spawalniczymi, głównie przez napawanie łukowe i natryskiwanie cieplne, pozwalała na przywrócenie im nominalnych kształtów i wymiarów, a także pozostałych parametrów oraz właściwości użytkowych. Intensywnie rozwijające się metody przyrostowe druku 3D pozwalają na budowę modeli i funkcjonalnych prototypów, w tym także części maszyn. W artykule przedstawiono autorskie prace zmierzające do zastosowania zrobotyzowanego napawania łukowego MIG/MAG w odmianie niskoenergetycznej CMT do budowy metalowych modeli 3D.

Słowa kluczowe: napawanie; drukowanie 3D; napawanie łukowe

\begin{abstract}
Hitherto practiced reconstruction of worn parts of machines using welding methods, mostly by arc welding and thermal spraying, allowed to restore the nominal shapes and dimensions, as well as other parameters and features. Intense development of 3D printing methods allow to build models and functional prototypes, including machine parts. The article shows own works which aim to use robotised arc welding MIG/MAG with a variation of low energy CMT to build 3D metal models
\end{abstract}

Keywords: 3D printing; pad welding; arc welding >>>

\section{Wstęp}

Terminem drukowania bądź modelowania 3D określa się zbiór metod służących do precyzyjnego i powtarzalnego wytwarzania elementów w oparciu o techniki przyrostowe (addytywne) [16,17], polegające na wielokrotnym nakładaniu warstw w celu osiągnięcia zakładanego kształtu i wymiarów. Pierwsze, współczesne metody druku 3D zaczęto stosować w latach osiemdziesiątych ubiegłego stulecia, a obecnie podlegają one niezwykle intensywnemu rozwojowi.

W odróżnieniu od konwencjonalnych metod produkcyjnych, zastosowanie druku 3D umożliwiło znaczne skrócenie procesu opracowania i wykonania modelu, prototypu, a nawet finalnego wyrobu, oraz ich łatwiejszą modyfikację (rys. 1).

Można wskazać kilka głównych obszarów zastosowania przyrostowego druku 3D [16]:

- Szybkie modelowanie (ang. Rapid Modeling) - szybkie wytwarzanie obiektów, zwykle mniej dokładnych i wytrzymałych w porównaniu do uzyskanych technikami tradycyjnymi, mogących pełnić funkcję modeli poglądowych, reklamowych, badawczych itp.

- Szybkie prototypowanie (ang. Rapid Prototyping) - wytwarzanie prototypów w możliwie najlepszy sposób naśladujących rzeczywisty obiekt, np. na potrzeby badań nowego wyrobu. a)

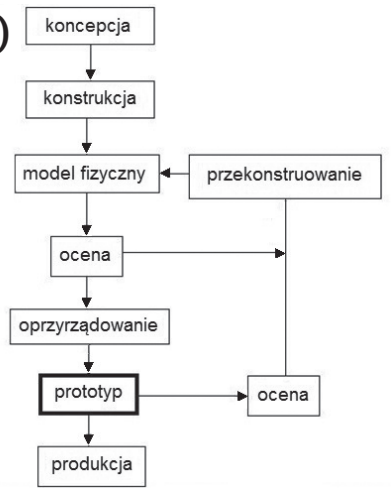

b)

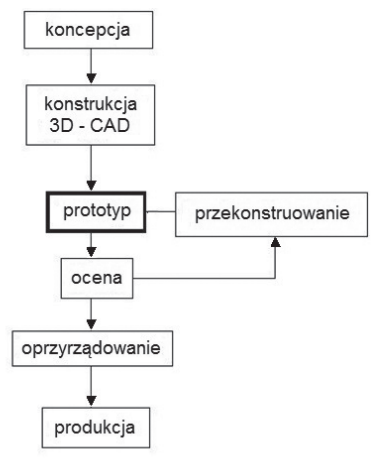

Rys. 1. Proces produkcji wyrobu, a) podejście tradycyjne, b) z wykorzystaniem metod rapid prototyping [13]

Fig. 1. The manufacturing process of the product, a) traditional approach, b) using rapid prototyping methods

- Szybkie wytwarzanie (ang. Rapid Manufacturing) - wytwarzanie w pełni funkcjonalnych obiektów, zarówno nowych urządzeń, jak i nietypowych części zamiennych, także na potrzeby medyczne (implanty dentystyczne).

- Szybkie wytwarzanie narzędzi (ang. Rapid Tooling) - wytwarzanie w pełni funkcjonalnych narzędzi, za pomocą których można wykonać nowe produkty, także w sposób konwencjonalny.

Dr inż. Paweł Cegielski; inż. Aleksandra Skublewska; inż. Paweł Gawroński; inż. Mateusz Ostrysz; inż. Michał Dylewski; inż. Mateusz Gajowniczek - Politechnika Warszawska.

Autor korespondencyjny/Corresponding author: pcegiels@wip.pw.edu.pl 
Dzięki modelowaniu 3D można wytwarzać przedmioty o często bardzo złożonych kształtach zewnętrznych i wewnętrznych, których wykonanie innymi metodami jest kłopotliwe, drogie, a nawet niemożliwe. Szczególnie pożądany wydaje się rozwój tanich i wydajnych technik druku 3D elementów metalowych, konkurencyjnych zwłaszcza dla tradycyjnych obróbek skrawaniem. W roku 2015 Amerykańska Federalna Administracja Lotnictwa po raz pierwszy dopuściła do użytku w silnikach produkowanych dla Boeinga część metalową wytworzoną w technologii druku 3D [14]. Wytwarzanie addytywne (druk 3D) stało się, obok robotyzacji, nowych materiałów i czujników oraz zbierania i raportowania danych „w chmurze”, jednym z głównych filarów nowoczesnej, tzw. inteligentnej fabryki (ang. smart factory), rozwijanej w ramach idei Przemysłu 4.0 [8].

\section{Odmiany drukowania 3D}

Ogół technik modelowania 3D obejmuje kilkadziesiąt metod formowania obiektów bezpośrednio z ciała stałego, a także z proszku, fazy ciekłej i gazowej [16]. Typowe, także domowe drukarki 3D, pozwalają na uzyskiwanie modeli z tworzyw sztucznych, a budowane w ten sposób przedmioty, w odniesieniu do części maszyn, mają najczęściej charakter jedynie poglądowy. W pełni funkcjonalne "wydruki” metalowe wymagają specjalnych, zaawansowanych metod wytwarzania, pociągających za sobą najwyższe nakłady. Wśród nich wskazać można metody komercyjne o charakterze spawalniczym, w tym m.in. $[7,9,16]$ :

- EBM (ang. Electron Beam Melting) - topienie metalowych proszków za pomocą wiązki elektronowej.

- SLS (ang. Selective Laser Sintering) - selektywne spiekanie laserowe proszków, najczęściej z tworzyw sztucznych (poliamidów) i metali.

- LENS (ang. Laser Engineering Net Shaping) - wytwarzania elementów z materiałów sproszkowanych poprzez ich miejscowe nanoszenie i spiekanie wiązką lasera. W przeciwieństwie do metody SLS/SLM proszek nie jest rozprowadzany w całej komorze roboczej, lecz dostarczany w ściśle określone miejsce. Dzięki temu metoda LENS pozwala także na miejscową naprawę (regenerację) istniejących części maszyn.

- SLM (ang. Selective Laser Melting) - selektywne stapianie proszków za pomocą wiązki laserowej. Lasery stosowane w metodzie SLM muszą mieć większą moc niż w SLS (w SLM materiał sproszkowany ulega pełnemu przetopieniu, dzięki temu wytworzone elementy nie mają porów).

- DMLS (ang. Direct Metal Laser Sintering) jest to unikalna nazwa metody SLM zastrzeżona przez niemiecką firmę Electro Optical Systems.

- LC (ang. Laser Cladding) - połączenie nawarstwiania sproszkowanego metalu topionego wiązką lasera i frezowania. Po zakończeniu nakładania kolejnej warstwy jej powierzchnia jest frezowana w celu usunięcia nierówności i niedokładności.

- Natryskiwanie cieplne, jako metoda uzupełniająca inny proces modelowania 3D.

- Natryskiwanie cieplne, jako metoda wytwarzania modeli 3D - strumień gazu pod wysokim ciśnieniem oddziałuje w sposób ciągły na strumień stopionego metalu, a powstałe kropelki są "rzucane" na model, tworząc gęstą powłokę nadającą kształt końcowy części.

Szybkie modelowanie, prototypowanie i wytwarzanie może, obok technik przyrostowych, wykorzystywać także metody ubytkowe, polegające na wytworzeniu obiektów z tworzyw konstrukcyjnych i stopów metali przez frezowanie na obrabiarkach CNC oraz z wykorzystaniem robotów przemysłowych zaopatrzonych w głowice frezujące.

\section{Zastosowanie napawania łukowego do drukowania 3D}

Spawalnicze, głównie laserowe techniki drukowania 3D oferują zwykle dokładne modele wysokiej jakości, lecz bazują jednak na niezwykle kosztownym sprzęcie i materiałach. Jest to często okupione także długim czasem powstawania wydruków. Z drugiej strony, od wielu lat dla wytworzenia nowego wyrobu o zmodyfikowanych właściwościach warstwy wierzchniej, a także w celach naprawczych i odtworzeniowych, znajdują zastosowanie znacznie prostsze i tańsze metody napawania, w tym bazujące na urządzeniach do spawania łukowego elektrodą topliwą w osłonie gazowej MIG/MAG (od ang. Metal Inert Gas/Metal Active Gas).

Napawanie łukowe jest procesem nakładania na powierzchnie metalowe stopiwa uzyskanego z topliwej elektrody, wymieszanego z nadtopioną warstwą wierzchnią materiału rodzimego. Metalurgiczne związanie warstwy napawanej z podłożem zapewnia wysokie walory użytkowe tak

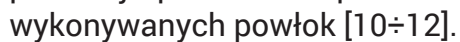

Na zużyte powierzchnie nanoszona jest warstwa stopiwa w celu przywrócenia im nominalnych wymiarów i kształtu, przy zapewnieniu odpowiedniej jakości, dokładności wymiarowej i właściwości eksploatacyjnych. Proces napawania łukowego może być zastosowany do naprawy uszkodzeń i ubytków na powierzchniach płaskich, obrotowych, o kształtach złożonych i w otworach, będących skutkiem ścierania, odłamania czy wyrwania fragmentu materiału.

O szerokim zastosowaniu i popularności napawania regeneracyjnego metodami MIG/MAG zadecydowały: rozpowszechnienie i dostępność urządzeń spawalniczych i materiałów dodatkowych, ich różnorodność (w tym drutów pełnych i proszkowych), duża operatywność procesu, wysoka wydajność i niskie koszty. Wyjątkowo korzystne efekty uzyskuje się przy mechanizacji i automatyzacji, w tym robotyzacji napawania $[11,15]$.

Wielowarstwowe napawanie łukowe w celach regeneracyjnych wykazuje pewne podobieństwo do przyrostowego drukowania 3D. O takim zastosowaniu napawania łukowego MIG/MAG mogły zadecydować takie właściwości jak m.in. [1,2]:

- dostępność i niski koszt maszyn oraz materiałów dodatkowych, w tym nowe metody niskoenergetyczne, wprowadzające ograniczoną ilość ciepła przy często znacznie lepszej kontroli i stabilności procesu, np. CMT (ang. Cold Metal Transfer, Fronius),

- łatwość sterowania procesem analogicznie do spawania MIG/MAG - źródła inwertorowe ze sterowaniem synergicznym,

- łatwość robotyzacji, kluczowa z uwagi na długotrwałe wytwarzanie złożonych form przestrzennych,

- powszechność stosowania do miejscowych napraw na powierzchniach części maszyn,

- wysoka wydajność stapiania, mogąca się przełożyć na krótki czas budowania modeli 3D.

Z drugiej strony, należy brać pod uwagę liczne obawy i ograniczenia napawania łukowego MIG/MAG, mogące negatywnie wpływać na budowę złożonych modeli 3D, w tym [1,2]:

- duża ilość ciepła, rosnąca w miarę postępowania procesu, mogącego wymagać kilkudziesięciu i więcej warstw,

- nieliniowy przyrost wysokości, deformacje i zapadanie się wydruku pod wpływem ciepła wprowadzanego do kolejnych warstw,

- niekorzystna struktura i właściwości mechaniczne będące skutkiem wielokrotnego i długotrwałego cyklu cieplnego,

- konwencjonalne metody napawania łukowego MIG/MAG pozwolą przede wszystkim na budowę modeli grubościennych i masywnych,

- mała dokładność i nieregularna powierzchnia ścian mo- 
delowanych obiektów, na poziomie odlewów czy odkuwek, wymagająca końcowej obróbki wykańczającej,

- mała dokładność, nieliniowość przyrostu i deformacje mogą stanowić istotne utrudnienie w całkowicie automatycznym przetworzeniu projektu graficznego CAD do postaci programu sterującego robotem,

- prawdopodobna konieczność stosowania dodatkowych czujników, np. temperatury (przerywanie procesu pomiędzy grupami warstw na czas częściowego wystudzenia) czy położenia (do oceny rzeczywistego przyrostu nakładanych warstw oraz ogólnie - rozmiarów budowanego modelu).

Pomimo licznych obaw i ograniczeń, od lat można było obserwować przejawy aktywności środowisk naukowych i inżynierskich dotyczących przyrostowego tworzenia obiektów 3D w oparciu o napawanie łukowe MIG/MAG. W roku 1992 Dickens, Pridham, Cobb i Gibson z Uniwersytetu Nottingham opublikowali „Rapid prototyping using 3-D welding”, prezentując idee wykorzystania wielowarstwowego napawania łukowego w celu budowania skomplikowanych, metalowych modeli przestrzennych [3,4]. Pierwsze części wytwarzane na zrobotyzowanym stanowisku miały charakter pionowych ścian i prostopadłościennych pudełek. Kolejnym etapem było wytwarzanie ścian skośnych o różnym stopniu nachylenia. Jednym z elementów docelowych był model termostatu dla samochodu marki Ford, który w warunkach produkcyjnych był odlewany. Dla uzyskania tak złożonej formy pochylano płytę bazową tak, aby kolejne warstwy zawsze przyrastały w kierunku pionowym. Szczegółowo analizowano wpływ szeregu parametrów napawania na budowane modele (tabl. I). Badania nie wykazały żadnych ubytków i wgłębień, nie stwierdzono także utleniania pomiędzy sąsiadującymi warstwami. Zauważono jednak niedoskonałości metody $[3,4]$ :

- ciepło podczas układania kolejnych warstw może powodować powtórne przetopienie spoiny, w tym ich częściowe zniekształcenie, a nawet załamanie się całej struktury; konieczne jest okresowe zatrzymywanie procesu lub dodatkowe chłodzenie modelu,

- niedokładność parametrów spawania i pozycjonowania robota może powodować narastające błędy, np. nadmierne zbliżanie lub oddalanie się uchwytu elektrodowego; konieczne jest zastosowanie czujników aktualizujących położenie robota względem modelu itp.,

- warstwy nie mogą utworzyć gładkiej powierzchni, mogą wystąpić lokalne szczeliny,

- maksymalna uzyskana dokładność wynosiła ok. $\pm 0,5$ $\mathrm{mm}$, a oczekuje się dokładności na poziomie $\pm 0,2 \mathrm{~mm}$.

Tablica I. Wpływ wybranych parametrów procesu na geometrię modeli 3D (fragment) [3,4]

Table I. The impact of the selected process parameters on the geometry of 3D models (fragment)

\begin{tabular}{|c|c|c|}
\hline \multirow{2}{*}{ Wzrost wartości } & \multicolumn{2}{|c|}{ Wpływ na mierzoną wartość } \\
\cline { 2 - 3 } Napięcie łuku & Szerokość ściegu & Wysokość ściegu \\
\hline $\begin{array}{c}\text { Szybkość } \\
\text { podawania drutu }\end{array}$ & $\uparrow$ & $\downarrow$ \\
\hline $\begin{array}{c}\text { Wolne } \\
\text { wysunięcie drutu }\end{array}$ & $\downarrow$ & $\uparrow$ \\
\hline $\begin{array}{c}\text { Średnica drutu } \\
\text { Średnica drutu }\end{array}$ & $\uparrow$ & $\uparrow$ \\
\hline
\end{tabular}

Wskazano następujące obszary zastosowania tego typu procesu drukowania 3D [3,4]:

- pojedyncze części lub małe partie produkowane bez specjalistycznego oprzyrządowania,

- narzędzia do produkcji innych części.

Pomimo szeregu zalet napawania łukowego oraz szerokiej dostępności coraz doskonalszych urządzeń, tylko niewielka liczba publikacji świadczy o jego wykorzystaniu do przyrostowego wytwarzania obiektów 3D. Obserwując czasopisma techniczne, publikacje naukowe oraz portale internetowe można natrafić na omówienia aplikacji oznaczanych nowym terminem WAAM (ang. Wire + Arc Additive Manufacturing) czy komercyjnym AMLTEC ${ }^{\text {TM }}$ (ang. Additive Metal Layering Technologies), zastrzeżonym dla firmy AML Technologies z USA. W rzeczywistości mowa tu o wielowarstwowym, precyzyjnie sterowanym napawaniu łukowym metodami MIG/MAG oraz TIG (z dodawanym, zwykle tzw. gorącym spoiwem).

Metody WAAM nakierowane są na budowę modeli ze stopów tytanu, niklu, stali czy aluminium, na potrzeby przemysłu ciężkiego, lotniczego i astronautycznego, samochodowego, morskiego, wydobywczego, obronności, energetyki jądrowej czy medycyny. Zwraca się uwagę na znaczną redukcję czasu i materiałów, możliwość wytwarzania z różnych stopów metali oraz łatwość robotyzacji procesu [17].

\section{Założenia techniczne i technologiczne eksperymentów}

Omawiane prace miały charakter wstępnego rozpoznania możliwości drukowania 3D w oparciu o zrobotyzowane napawanie łukowe MIG/MAG. Przyjęto następujące założenia techniczne i technologiczne:

- robotyzacja procesu z ręcznym programowaniem trajektorii, głównie poprzez wielokrotne powtórzenie zadanego konturu (rys. 2),

- modele wielowarstwowe - wielokrotne nakładanie warstw stopionego metalu z przyrostem w kierunku pionowym, poziomym lub skośnie),

- modele jednościegowe - ściana tworzona z pojedynczego, wielowarstwowego ściegu,

- ruch roboczy robota (kontury prostoliniowe) lub równoczesny ruch robota i obrotowego stołu pozycjonera (kontury kołowe),

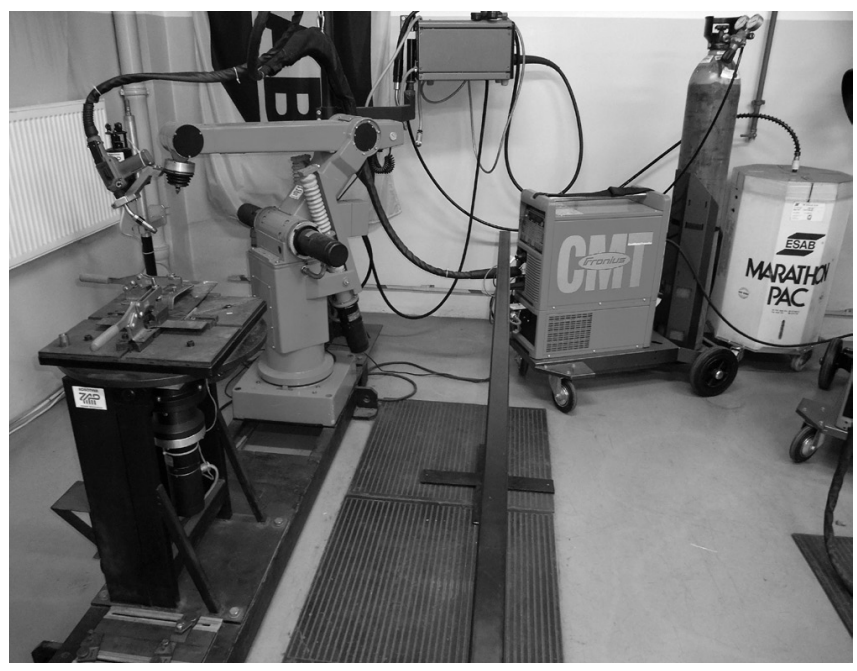

Rys. 2. Stanowisko laboratoryjne ze zmodernizowanym robotem spawalniczym IRp-6 i jednoosiowym pozycjonerem (ZAP Robotyka) oraz źródłem TPS 2700 CMT (Fronius)

Fig. 2. Laboratory workstation with a modernized welding robot IRp6, uniaxial positioner (Robotics) and TPS 2700 CMT (Fronius) 
- napawanie metodą MIG/MAG w odmianie niskoenergetycznej CMT (Fronius),

- wykorzystanie zaawansowanych trybów sterowania przebiegiem zasilającym łuk spawalniczy, uwzględniających zmodyfikowaną fazę startową i końcową cyklu (stopniowe narastanie lub opadanie prądu na początku i końcu napoiny),

- okresowe przerywanie procesu ze studzeniem modelu do ustalonej doświadczalnie temperatury (kontrola pirometryczna),

- kontrola przyrostu modelu wykonywana ręcznie suwmiarką cyfrową.

Komunikacja źródło - robot realizowana była poprzez interfejs cyfrowy ROB 3000 (Fronius) wspomagany wbudowaną procedurą spawalniczą robota IRp-6 oraz zdalnym sterownikiem RCU 5000i (Fronius). Kontrolę temperatury między warstwami napoin prowadzono pirometrem ELCOMETER 0020.

Z uwagi na wstępny charakter badań oraz ograniczenia samegorobota,poszczególnemodeleprogramowanobezpośrednio na stanowisku, bez pośrednictwa systemów CAD/CAM. Z drugiej strony, możliwe było szybkie wprowadzanie korekt, zarówno parametrów technologicznych, jak i trajektorii ruchu robota, w tym modyfikacja ostatecznej formy modeli.

Programowaniem objęto zarówno ruch robota i pozycjonera, jak i pracę spawalniczego źródła zasilającego łuk, w tym zadawanie parametrów pod postacią zaprogramowanych „jobów", uzupełnionych o specjalne nastawy źródła TPS 2700 CMT, dostępne podczas stosowania interfejsu komunikującego z robotem (rys. 3).

Programowaniem objęto zarówno ruch robota i pozycjonera, jak i pracę spawalniczego źródła zasilającego łuk, w tym zadawanie parametrów pod postacią zaprogramowanych „jobów", uzupełnionych o specjalne nastawy źródła TPS 2700 CMT, dostępne podczas stosowania interfejsu komunikującego z robotem (rys. 3), gdzie: 1 - gaz osłonowy przed zajarzeniem łuku, 2 - prąd w początkowej fazie spawania, 3 - dynamik przejścia pomiędzy poziomami prądu (ang. slope), 4 - zadany prąd spawania, 5 - prąd w końcowej fazie spawania, 6 - gaz ostonowy po spawaniu.

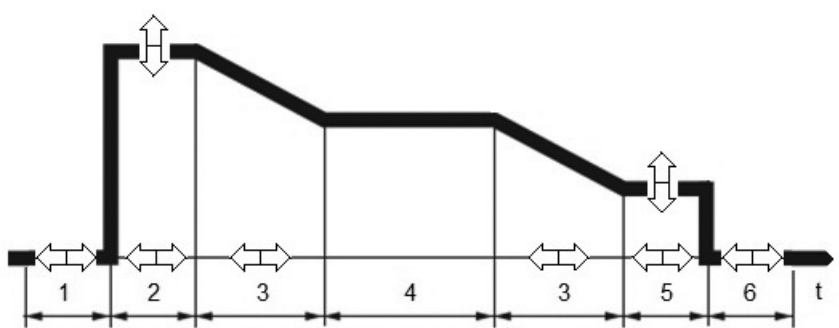

1 - gaz osłonowy - przed zajarzeniem łuku

2 - prąd w początkowej fazie spawania

3 - dynamik przejścia pomiędzy poziomami prądu (ang. slope)

4 - zadany prąd spawania

5 - prąd w końcowej fazie spawania

6 - gaz osłonowy - po spawaniu

Rys. 3. Złożony cykl spawania MIG/MAG z następującymi po sobie fazami wspomagającymi rozpoczęcie i zakończenie procesu spawania, z zaznaczonymi kierunkami ich edycji.

Fig. 3. Complex series of MIG / MAG welding with successive phases of supporting start and end of the welding process, with marked directions of their editing.

\section{Modele podstawowe}

Początkowe działania wiązały się z tworzeniem prostych form geometrycznych - pionowej ściany (płaskiej i narożnej) oraz walca tak, aby móc ustalić wyjściowe parametry technologiczne oraz ogólne zasady programowana robota i spawalniczego źródła. Już podczas wstępnych prób zrezygnowano z klasycznych odmian metody MIG/MAG (z pulsacją i bez) na rzecz procesu niskoenergetycznego CMT. Charakteryzowała go najwyższa stabilność, niemal całkowity brak rozprysku oraz widocznie mniejsza ilość ciepła wprowadzanego do modelu. Ponadto, możliwe stało się budowanie modeli precyzyjnych, gdzie grubość ścianki spadała nawet do $2 \mathrm{~mm}$.

Podczas wytwarzania płaskiej ściany nakładano na siebie kolejne napoiny o długości ok. $50 \mathrm{~mm}$ z każdorazowym, korekcyjnym podniesieniem uchwytu elektrodowego w kierunku pionowym. Walec o średnicy ok. $30 \mathrm{~mm}$ uzyskano z równoczesnego obrotu stołu pozycjonera i korekcyjnego podnoszenia uchwytu elektrodowego. W obydwu przypadkach napawano w pozycji podolnej z pionową orientacją uchwytu elektrodowego.

$\mathrm{Na}$ tym etapie pojawiły się istotne problemy związane z nakładaniem kolejnych warstw. Jednym z nich było nagłe "zapadanie" się (obniżanie profilu) napoiny po przebyciu przez łuk pierwszych 6 do $12 \mathrm{~mm}$. Zjawisko to ujawniało się powyżej trzeciej warstwy i pogłębiało w miarę dodawania kolejnych. Problem dotyczył zarówno profilu prostoliniowego, jak i walca. Ponadto, na końcu modelu płaskiej ściany obserwowano jego deformację - postępujące zaokrąglanie (rys. 4 i 5). Rozwiązaniem obydwu problemów było m.in. podzielenie konturu pojedynczej warstwy na szereg odcinków, wewnątrz których manipulowano prędkością ruchu robota oraz fazami złożonego cyklu spawania dostępnymi w źródle TPS 2700 CMT (rys. 3), w tym: wielkością prądu początko-

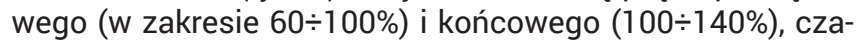
sami trwania obydwu faz $(0 \div 1 \mathrm{~s})$ oraz dynamiką przejścia pomiędzy fazami (funkcja slope, nastawiana w zakresie $0 \div 1 \mathrm{~s}$ ). Końcowym efektem było uzyskanie zadowalającej geometrii ścian oraz walców, chociaż wyraźny wzrost wysokości i pogrubienie w miejscu zmiany kierunku napawania dla modelu ściany narożnej wymagały dalszych korekt i doświadczeń (rys. 6).
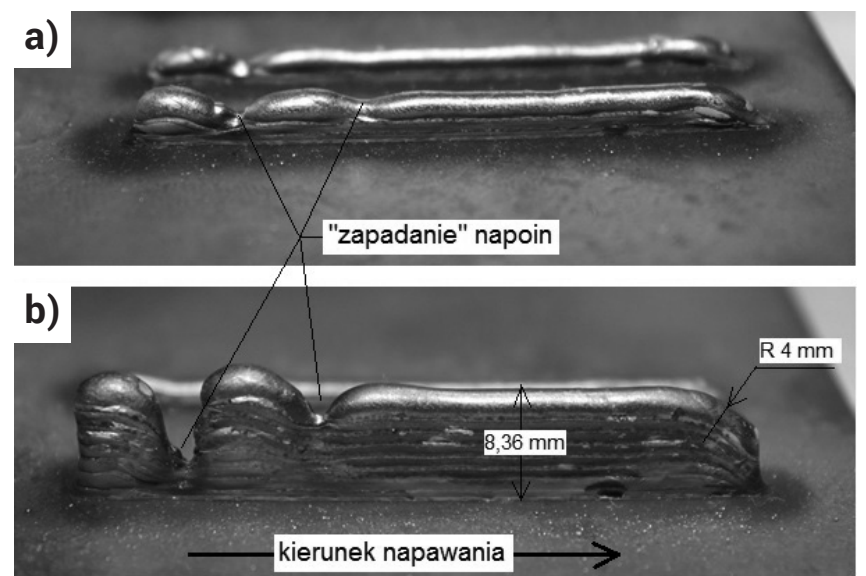

Rys. 4. Problemy ujawnione podczas pierwszych prób modelowania ściany: a) po 3 warstwach, b) po 8 warstwach [18]

Fig. 4. Problems revealed during the first attempts of modeling of the wall: a) after 3 layers, b) after 8 layers

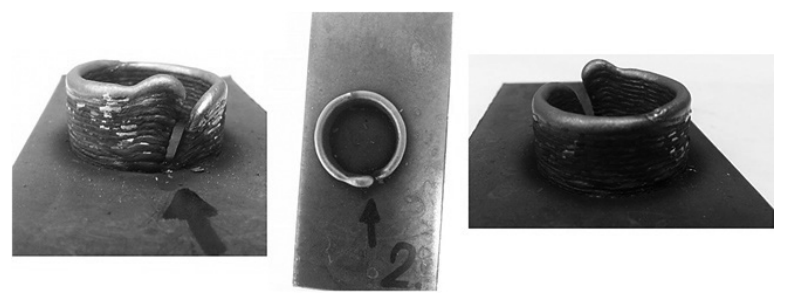

Rys. 5. Problemy ujawnione podczas pierwszych prób modelowania walca [5]

Fig. 5. Problems revealed during the first attempts of modeling of the cylinder 


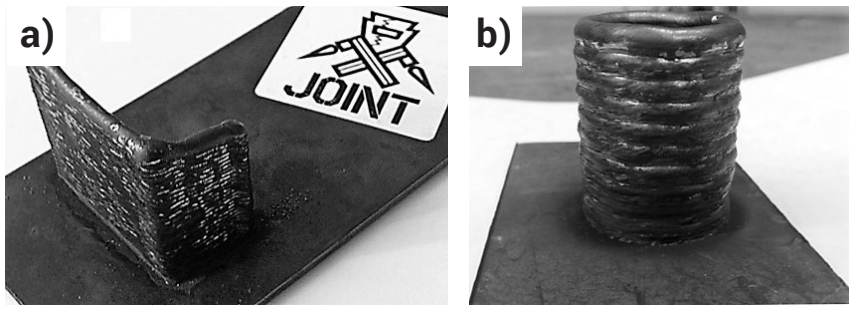

Rys. 6. Pierwsze udane modele uzyskane przez nałożenie ok. 30 warstw: a) ściana narożna [2], b) walec [5]

Fig. 6. The first successful models obtained by applying approx. 30 layers: a) a wall corner [2], b) the cylinder [5]

\section{Model pudełka}

Kolejny projekt obejmował wykonanie modelu o zamkniętym profilu w postaciotwartego od góry „pudełka" owymiarach zewnętrznych 28 x $50 \mathrm{~mm}$, średniej grubości ścianki 2,5 mm i wysokości od 20 do 30 warstw.

Z uwagi na prostą formę modelu, uzyskano go poprzez wielokrotne napawanie prostokątnego profilu $z$ każdorazowym podniesieniem korekcyjnym uchwyt elektrodowego. Zaprogramowano ruch względny robota z zadaną liczbą powtórzeń odpowiadających liczbie warstw modelu (rys. 7a i 7c). Zamknięty kontur złożony z prostoliniowych odcinków wymagał jednak opracowania skutecznej metody dla uzyskania niepogrubionych narożników oraz niezniekształconego zamknięcia kolejnych warstw. Z powodzeniem zastosowano tu wcześniejsze doświadczenia z podziałem pojedynczej warstwy na fragmenty o zmodyfikowanych parametrach, zarówno ruchu (prędkości napawania), jak i cyklu energetycznego łuku (rys. 3). Ostatnim akcentem było wykonanie uchylonego wieczka (rys. 6d), uzyskanego ze skośnego ustawienia uchwytu elektrodowego (oś elektrody pokrywała się z kierunkiem przyrostu pokrywy).
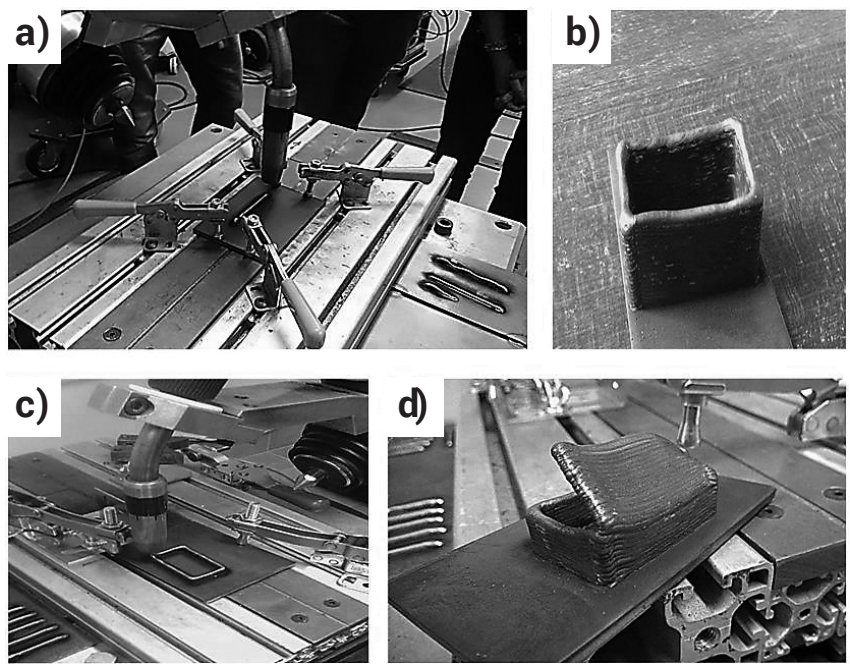

Rys. 7. Proces budowy modelu w formie pudełka: a) podkład zamocowany w przyrządzie, b) prawidłowo wykonany model podstawowy, c) proces budowania modelu złożonego z kolejno nakładanych profili, d) gotowy model z uchyloną pokrywą [2]

Fig. 7. The process of building the model in the form of a box: a) a primer mounted in the instrument, b) properly made base model, c) the process of building a model consisting of successively superimposed profiles, d) ready model with lid ajar [2]

\section{Model piasty}

Projekt wykonana piasty miał na celu wytworzenie złożonej części o charakterze użytkowym, uzyskanej w sposób alternatywny do konwencjonalnych technik wytwarzania. Obejmował on dwa etapy:
- wytworzenie walcowej podstawy o średnicy ok. $30 \mathrm{~mm}$, wysokości $40 \mathrm{~mm}$ i grubości ścianki ok. $4 \mathrm{~mm}$ (analogicznie do wcześniej omawianego walca, rys. 5 i 6b),

- dobudowanie kołnierza montażowego piasty o średnicy zewnętrznej ok. $60 \mathrm{~mm}$ i grubości ścianki ok. $3 \mathrm{~mm}$, położonego na wysokości $25 \mathrm{~mm}$.

Każdorazowo programowano ruch obrotowy stołu pozycjonera z korekcyjnym odsuwaniem uchwytu elektrodowego - pionowo dla walca oraz poziomo dla kołnierza (rys. 8).

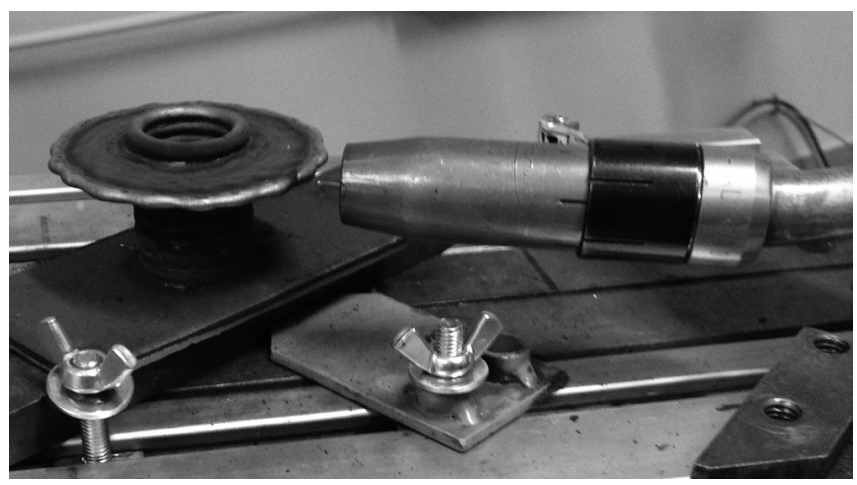

Rys. 8. Proces tworzenia kołnierza piasty z poziomym odsuwaniem uchwytu elektrodowego

Fig. 8. The process of creating a hub flange with horizontal postponing of the electrode holder

Pierwsze próby wykazały znaczne nagrzewanie się walca (złożonego z 30 do 36 warstw) oraz towarzyszące temu stopniowe zapadanie się metalu do jego wnętrza. Uzyskanie tak wysokiego elementu o poprawnej geometrii wiązało się z wprowadzeniem kontroli temperatury i studzeniem pomiędzy grupami warstw. Po wykonaniu cyklu trzech warstw proces zatrzymywano aż do ostygnięcia modelu do temperatury $80 \div 140{ }^{\circ} \mathrm{C}$ (zależnie od wariantu), kontrolowanej ręcznym pirometrem. Również w przypadku kołnierza proces przerywano po każdych trzech warstwach, przy ich łącznej liczbie 18 [5]. a)

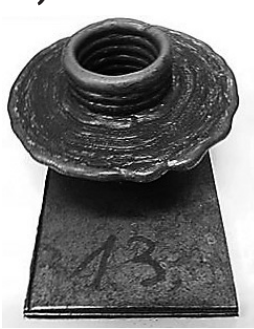

b)

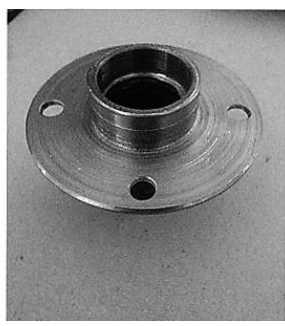

c)

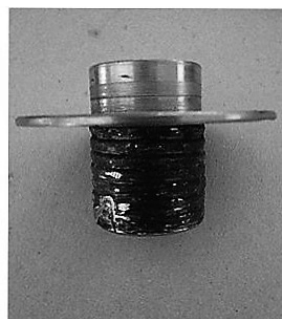

Rys. 9. Piasta wytworzona poprzez napawanie łukowe MAG CMT: a) surowy model z płytką bazową, piasta po obróbce wykańczającej, c) piasta częściowo obrobiona [5]

Fig. 9. The hub generated by the arc welding MAG CMT: a) the stark model with base plate, the hub after finishing, c) partially machined hub [5]

Po wykonaniu każdego cyklu trzech warstw kontrolowano, oprócz temperatury, także geometrię modelu (rys. 10), w tym średnią wysokość walca (h) i grubość jego ścianki (s) oraz średni przyrost szerokości kołnierza (p) i grubość jego ścianki (g). Pomiarów dokonywano ręcznie suwmiarką cyfrową, powtarzając pomiar w wielu miejscach na obwodzie walca i kołnierza. Wytworzone modele charakteryzowały się dobrą powtarzalnością wymiarową (średnio $\pm 0,5 \mathrm{~mm}$ ), a stan powierzchni nie odbiegał od standardowych wyrobów odlewanych czy kutych (rys. 9a). Pomimo wcześniejszych obaw, stwierdzono niemal liniowy przyrost wysokości walca oraz szerokości kołnierza, przy tylko nieznacznie zmieniających się grubościach obydwu elementów (rys. 10). 
a)

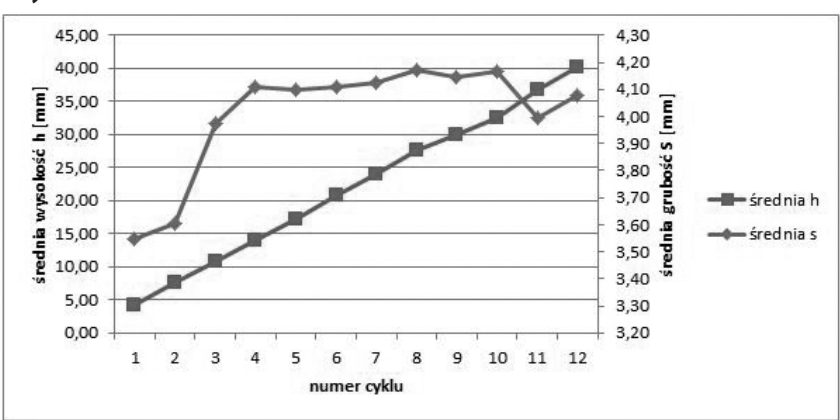

b)

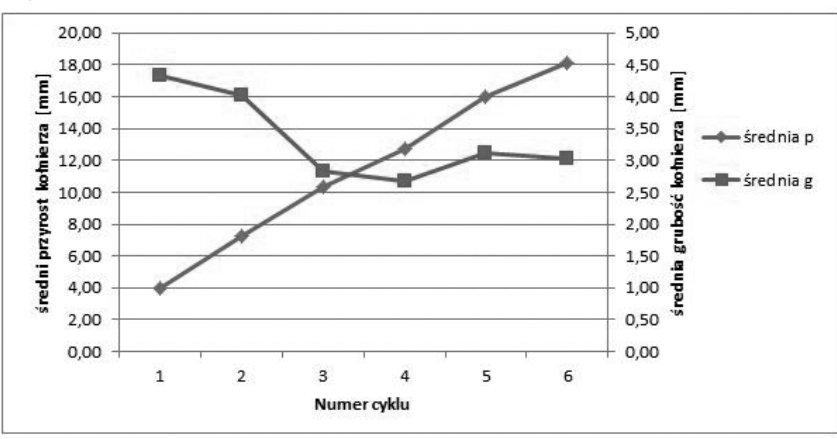

Rys. 10. Geometria modelu piasty (próba nr 13): a) walec (36 warstw w 12 cyklach), b) kołnierz (18 warstw w 6 cyklach) [5]

Fig. 10. Geometric hub model (sample No. 13): a) a cylinder (36 layers of 12 cycles), b) a flange (18 layers 6 cycles) [5]

$\mathrm{Na}$ zakończenie przeprowadzono częściową obróbkę wykańczającą przez toczenie (rys. 9b-c). Po zakończeniu badań wizualnych kilka modeli wytypowano do badań metalograficznych. Mechanicznie wycięto elementy walca i kołnierza tak, aby uzyskać obraz wpływu kolejnych warstw walca i kołnierza na strukturę modelu. Pobrane próbki wyszlifowano i wypolerowano, następnie trawino nitalem przez około $30 \mathrm{~s}$. Uzyskane zgłady metalograficzne obserwowano na mikroskopie optycznym z cyfrową rejestracją obrazu (rys. 11-13).

Badania makroskopowe (rys. 11) wykonane w powiększeniu 10-krotnym pokazują jednorodną strukturę modelu. $\mathrm{Na}$ zarysie powierzchni zgładu widoczne są niewielkie i rzadko występujące porowatości. Widoczne pofalowanie wynika z wytwarzania modelu w cyklach. Powierzchnia zgładu jest wolna od pęknięć i pęcherzy podskórnych oraz jam skurczowych. Na rysunku 12 widoczne są granice pomiędzy cyklami w postaci baryłkowatości powierzchni, można także zauważyć odbarwienia i przyklejone drobne rozpryski spawalnicze. Badania mikroskopowe (rys. 13) ujawniły pozytywny wpływ kolejno dobudowywanych warstw na już wytworzone - odpuszczanie naprężeń spawalniczych oraz rekrystalizację. Warstwa wytworzona jako ostatnia miała mikrostrukturę charakterystyczną dla spoiny, natomiast pozostałe ferrytyczno - perlityczną. Po obróbce wykańczającej, w wyniku której usuwana jest ostatnia napawana warstwa, pozostaje mikrostruktura charakterystyczna dla stali, pozytywnie wpływając na właściwości użytkowe całego modelu.

\section{Model punktowy}

Zaawansowanym rozwinięciem metody CMT jest m.in. opracowany przez firmę Fronius proces CMT Print. Polega on na w pełni kontrolowanym odrywaniu pojedynczej kropli metalu od elektrody, która w końcowym efekcie tworzy kulkę na powierzchni materiału podstawowego. Cykl cieplny składa się z dwu faz: podgrzewania i zapłonu, a następnie chło-

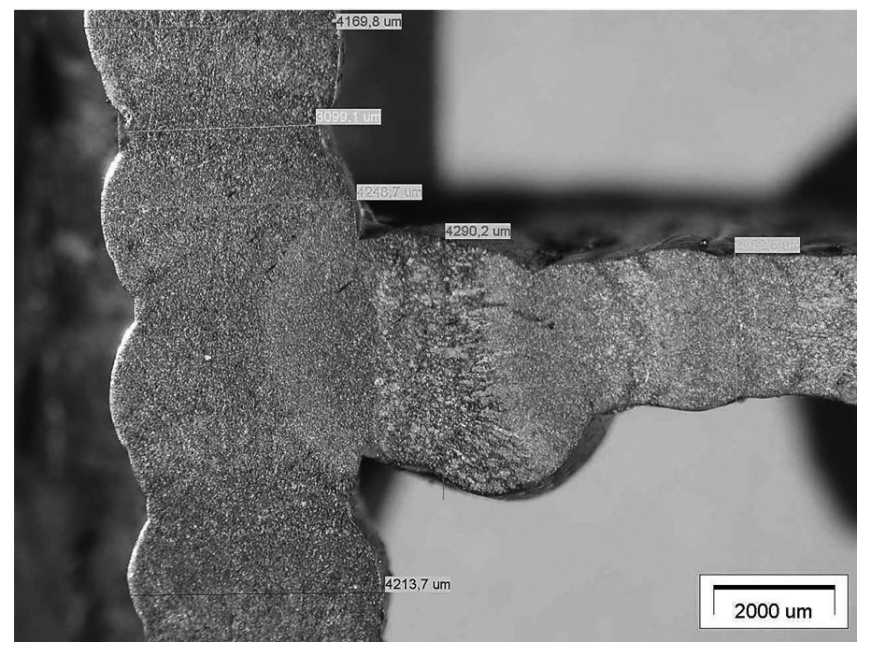

Rys. 11. Obraz obszaru walca i pierścienia piasty przy powiększeniu $x 10$

Fig. 11. Image of the cylinder area and ring of the hub at 10x magnification

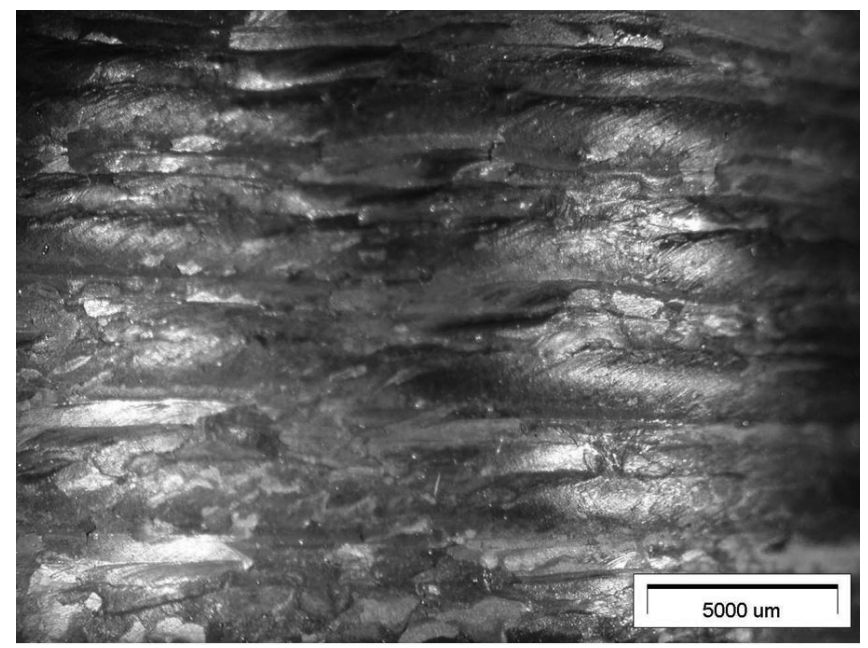

Rys. 12. Makrostruktura powierzchni walcowej piasty przy powiększeniu $\times 10$

Fig. 12. Macrostructure of cylindrical surface of the hub at 10x magnification

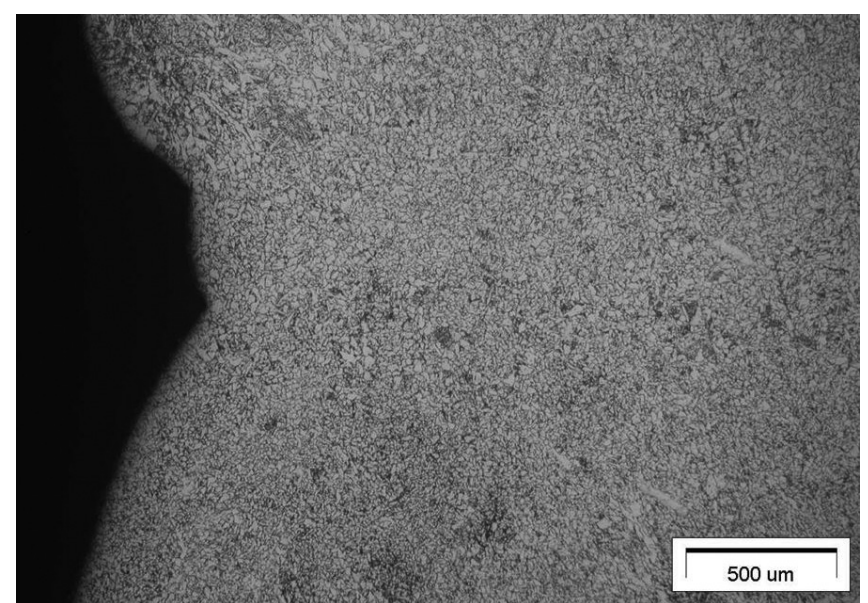

Rys. 13. Makrostruktura powierzchni walcowej piasty przy powiększeniu $\times 10$

Fig. 13. The microstructure of the cylindrical part on the border between the layers at a magnification of $x 50$

dzenia i kształtowania. Proces ten może zostać porównany bezpośrednio do drukowania.

Jak pokazały pierwsze doświadczenia, sama metoda jest bardzo stabilna i powtarzalna, pozwalając na precyzyjne 
położenie jednej kulki na drugiej. Teoretycznie, możliwe jest zatem budowanie przestrzennych modeli o bardzo małych rozmiarach. W rzeczywistości łatwa okazała się jedynie budowa słupków złożonych kolejno nakładanych, pojedynczych kropli, zarówno pionowych, jak i skośnych (podążających za odchyloną elektrodą), a także odgałęzionych (rys. 14). Na rysunku 15 pokazano strukturę metalograficzną wypreparowaną z jednego ze słupków.

Przedstawiony obraz metalograficzny potwierdza złożony cykl cieplny towarzyszący procesowi CMT Print, widoczne są kolejne warstwy oraz wpływ wielokrotnego cyklu cieplnego oddziałującego na model.

Niestety, dotychczas nie udało się zbudować modelu w formie wielościegowej, wielowarstwowej ściany. Nawet drobne błędy uzyskane $\mathrm{w}$ fazie początkowej potęgowały się w kolejnych fazach procesu (rys. 16).
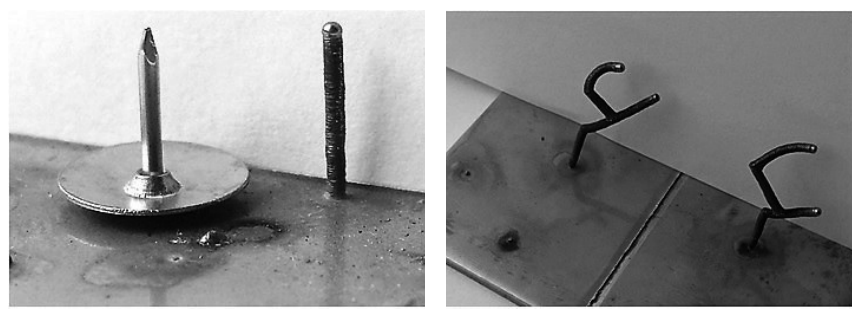

Rys. 14. Efekty pierwszych prac nad drukowaniem 3D w oparciu o proces CMT Print. Średnica słupków ok. $1 \mathrm{~mm}$ [6]

Fig. 14. The effects of the early work on the $3 D$ printing process based on CMT Print. The diameter of the posts approx. $1 \mathrm{~mm}$
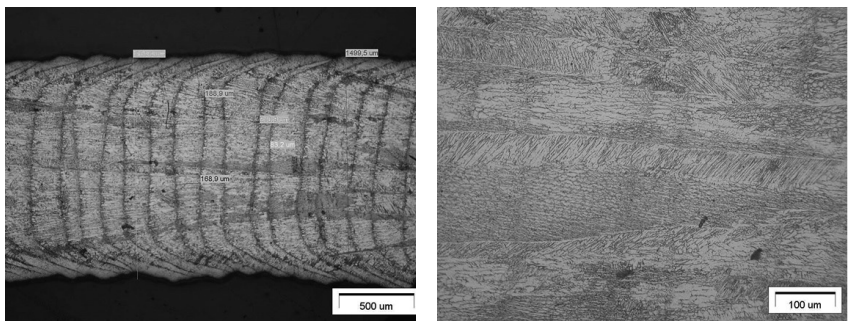

Rys. 15. Struktura metalograficzna słupka uzyskanego w procesie CMT Print (przy powiększeniu 50 i 200) [6]

Fig. 15. Metallographic structure of the post obtained in the process of CMT Print (with magnification of 50 and 200)

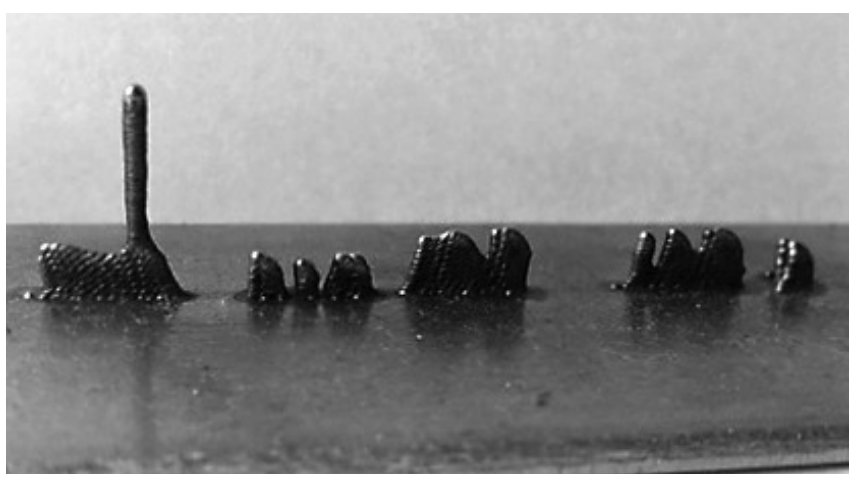

Rys. 16. Próba zbudowania ścian przy wykorzystaniu metody CMT Print [6]

Fig. 16. Attempt of building walls using CMT Print method

Tablica II. Wybrane obawy i problemy przy modelowaniu 3D przez napawanie tukowe MIG/MAG CMT i sposoby ich rozwiązania Table II. Selected concerns and problems with 3D modelling by arc welding CMT MIG/MAG and ways to resolve them

\begin{tabular}{|l|l|}
\hline \multicolumn{1}{|c|}{ Obawa, problem } & \multicolumn{1}{c|}{ Rozwiązanie } \\
\hline Duża ilość ciepła wprowadzana do modelu & $\begin{array}{l}\text { Okresowe przerywanie procesu w celu wystudzenia modelu, } \\
\text { a następne wznowienie }\end{array}$ \\
\hline Deformacje i zapadanie się modelu & $\begin{array}{l}\text { Problem nie występuje, jeśli wprowadzi się przerwy między gru- } \\
\text { pami warstw }\end{array}$ \\
\hline Nieregularny przyrost warstw & $\begin{array}{l}\text { Przyrost wysokości modelu stabilizuje się w miarę dodawania } \\
\text { warstw; mniej regularnie zachowuje się grubość napawanych } \\
\text { ścianek }\end{array}$ \\
\hline $\begin{array}{l}\text { Stosując napawanie metodami łukowymi otrzymuje się jedynie } \\
\text { masywne modele }\end{array}$ & $\begin{array}{l}\text { Metody niskoenergetyczne, jak CMT, umożliwiają budowę modeli } \\
\text { precyzyjnych, cienkościennych, o znacząco ograniczonej ilości } \\
\text { ciepła wprowadzanego do modelu }\end{array}$ \\
\hline Mała dokładność i nieregularna powierzchnia modelu & Wymagana jest obróbka końcowa \\
\hline Złożone sterowanie pracą źródła i robota & Wymaga podejścia zintegrowanego CAD/CAM \\
\hline
\end{tabular}

\section{Podsumowanie}

W wyniku wstępnych prac nad zastosowaniem napawania łukowego MIG/MAG w odmianie CMT i CMT Print do przyrostowego drukowania 3D zdobyto unikalną wiedzę i doświadczenie, pozwalające na wykonanie szeregu modeli przestrzennych, także o walorach użytkowych (piasta).

Połączenie procesu napawania niskoenergetycznego CMT z precyzyjnie zaprogramowanym ruchem roboczym robota spawalniczego i pozycjonera oraz złożonym cyklem zasilania łuku spawalniczego daje nadzieję na budowę funkcjonalnych, przestrzennych modeli i prototypów.

Przewidywane i stwierdzone w trakcie badań obawy i problemy w znacznym stopniu udało się rozwiać lub rozwiązać (tabl. II).

W odniesieniu do metody CMT Print spodziewano się możliwości swobodnego „drukowania” złożonych form przestrzennych. Niestety, jak dotychczas możliwe było wytworzenie jedynie wielowarstwowych, jednościegowych słupków (prostych, skośnych i odgałęzionych). Nie umniejsza to jednak potencjału tej zaawansowanej metody. 
W stosunku do innych, spawalniczych metod modelowania 3D, stosując napawanie łukowe MIG/MAG można spodziewać się nawstępujących, głównych korzyści:

- Rozmiar modeli ograniczony jest praktycznie tylko zasięgiem ramienia robota, a w przypadku zastosowania dodatkowej osi, np. toru jezdnego, istnieje możliwość wytworzenia bardzo dużych elementów.

- Krótki czas wytworzenia modeli (opisana piasta wytwarzana była w czasie 60 $\div 90$ minut, w zależności od liczby cykli oraz temperatury schładzania pomiędzy nimi).

- Niskie koszty oraz łatwa dostępność maszyn, oprzyrządowania i materiałów dodatkowych.

- Wysokie parametry użytkowe modeli.

\section{Literatura}

[1] Cegielski P. Nowe obszary zastosowania napawania łukowego MIG/MAG Przegląd Spawalnictwa 6/2016, str. 48-49.

[2] Cegielski P., Skublewska A., Gawroński P., Ostrysz M., Dylewski M., Gajowniczek M. Zastosowanie napawania łukowego MIG/MAG do drukowania 3D Spajanie 2/2016, str. 22-26.

[3] Dickens P.M., Cobb R., Gibson I., and Pridham M.S., Rapid Prototyping Using 3D Welding, Journal of Design and Manufacturing 3/1993.

[4] Dickens P.M., Pridham M.S., Cobb R., Gibson I. (1992) Rapid Prototyping Using 3D Welding, Proceedings of the 3rd Symposium Solid Freedom Fabrication, Austin, Texas, 9/1992, str. 280-290.

[5] Gajowniczek M. Zrobotyzowane modelowanie 3D z wykorzystaniem napawania łukowego metodą CMT MAG, praca dyplomowa pod kierunkiem dr inż. Pawła Cegielskiego, Politechnika Warszawska 2016.

[6] Gawroński P. Zrobotyzowane modelowanie 3D z wykorzystaniem metody CMT Print, praca dyplomowa pod kierunkiem dr inż. Pawła Cegielskiego, Politechnika Warszawska 2016.

[7] Hiemenz J., Electron beam melting, Advanced Materials \&. Processes 165 (2007).

[8] Iwański T., Gracel J. Co przemysł 4.0 oznacza dla automatyków? Biuletyn Automatyki, Astor, 2/2016, str. 15-17.
[9] Khan M., Dickens P. Selective laser melting (SLM) of gold (Au) Rapid Prototyping Journal 18/2012.

[10] Klimpel A. Napawanie i natryskiwanie cieplne WNT Warszawa 2000.

[11] Kolasa A, Sarnowski T., Cegielski P. Regeneration of Worn Out Machine Parts Surfaces by Aut. Welding Przegląd Spawalnictwa 1/2015, str. 50-57.

[12] Kolasa A. Uszkodzenia i naprawy metalowych części maszyn, Wydawnictwa Politechniki Warszawskiej, Warszawa 1997.

[13] Miecielica M. Techniki szybkiego prototypowania - Rapid Prototyping. Przegląd Mechaniczny 02/2010, str. 39-45.

[14] Poreda R. REXIO - zrobotyzowane rozwiązanie do zadań specjalnych Biuletyn Automatyki, Astor, 2/2016, str. 29-31.

[15] Sarnowski T., Cegielski P., Kolasa A. Stanowisko do automatycznego napawania płyt stalowych, Przegląd Spawalnictwa 10/2011, str. 12-15.

[16] Siemiński P., Budzik G. Techniki przyrostowe. Druk 3D. Drukarki 3D Oficyna Wydawnicza Politechniki Warszawskiej, Warszawa 2015.

[17] Uziel A. Looking at Large-Scale, Arc-Based Additive Manufacturing WeIding Journal 4/2016, str. 42-46.

[18] Żurek K. Szybkie prototypowanie z wykorzystaniem napawania łukowego metodą MAG, praca przejściowa inżynierska pod kierunkiem dr inż. Pawła Cegielskiego, Politechnika Warszawska 2014. 